\title{
Translation versus Adaptation in Spain and England
}

\author{
Kenneth Muir \\ Formerly of the University of Liverpool
}

\begin{abstract}
The differences between the Elizabethan theatre and the theatre of our day are so enormous that adaptations are necessary. The gulf between the English secular stage and the Catholic stage of the Golden Age makes straightforward translations impossible. Although adaptations are inevitable, they are regrettable necessities. It is better to reveal Shakespeare in his world than to believe that he is our contemporary.
\end{abstract}

In view of the title of this paper, I should mention its origin. Years ago I was interviewed on the adaptation of Henry $V I$ at Stratford by John Barton, who had cut half of Shakespeare's lines and added a thousand of his own composition. I was asked whether I approved of adaptations. I replied that I had no objection to them-if and when they improved on the originals. I remembered the mess made by Dryden of Troilus and Cressida and The Tempest and the shocking travesty of $A$ Winter's Tale committed by the great actor Garrick. Was Barton likely to succeed where Dryden and Garrick had failed? At least he had the excuse that Henry VI was not one of Shakespeare's masterpieces.

Nevertheless there are occasions when adaptations are inevitable-regrettable necessities - and others that are difficult to excuse. Fitzgerald, for example, always assumed that his taste was superior to Calderón's and he altered the plays accordingly. In The Mayor of Zalamea he turned the soliloquy of the raped daughter into prose, because the great poetry of the original was far too good for a peasant-girl. More recently there was a production at Stratford-on-Avon of Tirso de Molina's archetypal play about Don Juan, in which the valet was metamorphosed into a female of uncertain age-apparently they supposed a willing bawd was less offensive than an unwilling pimp. Molière and Mozart would have turned in their graves.

In Shakespeare en España José Manuel González interviewed five directors of Shakespeare's plays. Most of them deplored the adaptations of others-notably a Hamlet oddly depicted as a Nazi, and the suicide of Goneril in King Lear by injecting an overdose of heroin. But all those directors assumed that adaptation was necessary. Indeed the first 
Shakespeare play to be introduced to Spanish audiences in 1772 was an adaptation from the French of Ducis, which was itself a crude adaptation of the original play. Although an accurate translation of Shakespeare by Moratin was published in 1798, the Othello of 1812 again relied on Ducis.

To an English ear the best translation of Shakespeare is that being carried out by Manuel Conejero and his colleagues in Valencia. Conejero keeps abreast of Shakespeare scholarship, but he is also an actor and director. This enables him to gauge the effect of his lines on an audience. But it is worth noting that his productions are sometimes-perhaps always-adaptations. One critic of his production of Twelfth Night declared that he had taken enormous risks, but that he had emerged triumphantly successful. The production was based on the fact that there were no actresses on the Elizabethan stage. We are told that the play was a festival of Love, in all senses of the word, including erotic. Everything was permitted. It was an orgy, alternating bi-sexuality and transvestism, and resulted in a dream of love, and tender whispering. One can understand how the main quartet-Orsino, Viola, Olivia and Sebastian could be treated in this way. So, perhaps, could Maria and Sir Toby. But most of the other characters could not. ${ }^{1}$ In any case, one can be sure that Elizabethan audiences accepted the convention that boys could play female roles. It is notable that Shakespeare took great pains to reduce physical contact between the lovers. Orsino does not kiss Viola until she puts on female clothing. I can see no evidence to support Professor Jardine's view that Shakespeare exploited the convention in order to appeal to the homosexuals in the audience (see Jardine).

When Jan Kott declared that Shakespeare was our contempory, he meant merely that he seemed relevant to each new generation. He was aware that Shakespeare was the contemporary of Queen Elizabeth and King James, of Sidney and Spenser, of Donne and Campion, of Burton and Hooker, of Mary, Queen of Scots and the Gunpowder Plot, of Marlowe and Jonson. The audience at the Globe had different beliefs and different superstitions from ours. The replica of the Globe now being erected on the South Bank will doubtless tell us a lot about Shakespeare's stagecraft, but the audience will be different in every way; it will be better educated and less smelly; it will expect greater comfort; and already fire-regulations have dramatically reduced the size of the audiences.

If a 1995 audience in England differs radically from one in 1600, the difference between Spanish and English theatres is very much greater. The English theatre was secular; although dramatists could write on some biblical stories, they had to avoid those essential to the Christian faith. Shakespeare probably inherited sympathy for the old faith, but he could not express this directly; whereas the Spanish dramatists were devout catholics writing for catholics. I suggested years ago that this was a disadvantage (Muir). I now think that the greater dramatists managed to exercise considerable freedom. Lope's great tragedy, El castigo sin venganza arouses sympathy for the incestuous lovers, who know they are damned, and no sympathy at all for the dreadful husband whose murder of his wife and son gives the ambiguous title to the play. I believe that some learned Hispanists make the mistake of trying to be more othodox than the dramatists.

Of course our perceptions of Shakespeare's plays are continually changing, sometimes because of the historical situation. Leslie Sands-a fine actor and successful dramatist-in 
his account of his early years recalls his first starring role as Coriolanus in the middle of the Second World War:

This was to be Shakespeare in modern dress, and the two opposing factions would not represent the battles of Ancient Rome but would reflect, with surprising aptitude, the European conflict as we then knew it.

To this end, the Romans were to be modern fascists, with Coriolanus and his cohorts in uniforms almost as dazzling as those of Il Duce himself and the Volscians would be in British khaki. Rudolf Hess ... had recently flown alone to Scotland to try and arrange a negotiated peace. In this production when Corriolanus defected to the Volscians he came on stage unshackling the harness of a parachute. (Sands 211-14)

As I was the director of this production, and still possess the prompt-copy, I was in a good position to put the record straight. During the rehearsals the Volumnia fell ill. Her place was taken by a good and mature actress; but the play was revived some weeks later, so that the recuperated actress could play the part. In the interval Hess landed in Scotland. The incident in which Coriolanus divested himself, of his parachute was pure fantasy. It was doubtless suggested by the Prologue I wrote for the occasion.

When last we acted here, although we knew
That History had studied Shakespeare too,
We were unconscious prophets; did not guess
That in the wings there waited RUDOLF HESs.
O blest sensation! O amazing scoop!
Conversion worthy of the Oxford Group!
O rival to the monster of Loch Ness!
"This decent Nazi" said the Evening Press.
"This idealist," to quote The Times,
"Tired of his fellow-gangsters' odious crimes."
Or did he find, as wiser papers urged,
That he the purger would become the purged?
Knowing the Nazis would not always win.
Or fearing for his tough and blood-stained skin
He took a plane and dropped by parachute,
Hoping we'd all forget he was a brute.
We gave him chicken, caviare and wine
Casting our pearls before an obvious swine.

As we did not have enough men to stage the battle-scenes of the first act, they were relayed on the radio (in imitation of the Home and Overseas service of the B. B. C.) with Volumnia and Virgilia hanging on every word. There was a repetition of the same device when the Volscian radio recorded the arrival of Coriolanus.

Apart from this there was no substantial alteration of Shakespeare's text. Yet, as Sands recorded, the attitude of the audience was inevitably transformed. The aristocrats-except Virgilia-were regarded as Machiavels; the common people, far from being a mob, were 
rational and obviously in the right. Even the Tribunes were realistically defending their class. No other interpretation could have been accepted in the summer of 1942.

Fashionable critics have had an equally significant influence on our interpretation of the plays. In my 75 years of playgoing there have been momentous changes. This can be illustrated by the fate of a single play, Hamlet. I have watched the Hamlet of A. C. Bradley and that of his critic, Stoll; Madariaga's hostile appraisal; the pacifist Hamlet of Middleton Murry and his followers; the Olivier film version of a character who could not make up his mind; the immature Hamlet admonished by Scrutiny critics, Wilson Knight's early character who was morally inferior to a penitent Claudius; the Freudian Hamlet suffering from Oedipus complex; the student who wants to return to Wittenberg to complete his doctoral thesis; the C. S. Lewis Everyman, burdened with Original Sin; the existential Hamlet; the wicked man who is condemned for attempting to obey his father's commands; a Hamlet who did not delay, but killed Claudius as soon as he could do so without harming Gertrude-these were all partial interpretations and quite different from the complex character revealed in the texts of the play.

One can see the necessity not merely of adapting Spanish plays in England and of English plays in Spain, but of Spanish plays in Spain and English plays in England. Nevertheless, something of vital importance is lost. It was found again during the "twenties and 'thirties when it was possible to get a seat at the Old Vic for less than a packet of cheap cigarettes, and see productions of Shakespeare almost without cuts played by brilliant actors and actresses-Gielgud, Olivier, Swinley, Richardson, Sybil Thorndike, Edith Evans, Peggy Ashcroft.

When a decade later I had my first chance of directing plays, I tried to follow in the Old Vic tradition but working with an amateur cast. The company was called The York Settlement Community Players. They had a long and honourable record of performing nothing but masterpieces. Every year a Shakespeare play, usually a foreign play in translation-Molière, Ibsen, Tchekov-and a modern play by Yeats, O'Casey, O'Neill. They would have been outraged if anyone had suggested the production of a west-end comedy. This is the more remarkable when one considers that most of the players had left school at 15 and had no educational qualifications. As they put on only four productions a year, they could spend three months on each one. I had already directed Rosmersholm and translated two French plays for them, and acted in Twelfth Night, when they invited me to produce Hamlet. First of all they asked me to hold a series of Seminars to discuss the play with them; then they asked me to spend several weeks in training them to speak the verse; and only then did they allow me to begin rehearsals. It was a wonderful opportunity and a humbling experience for me when I realised that these educationally deprived people had a passion for great drama which many of my own students apparently lacked. The production was well reviewed and every seat was filled for each of the five performances. At the last we had to turn away some thirty people who had failed to book.

My other productions included Troilus and Cressida and King Lear. The man who played Hamlet, Troilus and Edmund enlisted in 1939 and despite his lack of education he soon became a colonel-his playing of princely parts was of more use than a normal education. The man who played Ulysses and Lear was so much admired by Archbishop Temple that he was invited to Bishopthorpe Palace so that he could be thanked for the 
pleasure he had given now he was leaving for another job. I mention these facts because they reinforced my belief in the advantages of plain Shakespeare, in that it enables the participants to exercise their imaginations in order to understand Shakespeare and his world-a more salutary feat than relying on adaptations to show them the relevance of the plays in the modern world-necessary though that is.

\section{Notes}

1. Manuel Ángel Conejero was the author of a book on adolescent sexual experimentation.

\section{Works Cited}

Jardine, Lisa. Still Harping on Daughters. Brighton: Harvester, 1983.

Muir, Kenneth. "The Advantages and Disadvantages of Secularity." Parallel Lives. Ed. L. and P. Fothergill-Payne. Bucknell UP, 1991. 211-23.

Sands, Leslie. Tuppence for the Rainbow. 1990. 